Research Article

\title{
28 Days Toxicity Study of the Hydroalcoholic Extract Rhizome of Curcuma longa, Flowers of Cordia lutea, Leaves of Annona muricata, Fruit of Citrus aurantifolia, Fruit of Myrciaria floribunda and Leaves of Aspidosperma spruveanum in Rats
}

\author{
José Cabanillas-Coral ${ }^{1}$, Lester Dominguez Huarcaya ${ }^{2 *}$ \\ 1. External Investigator, Lima-Perú. \\ 2. Norbert Wiener University. Postgraduate Unit, Lima - Perú. \\ *Corresponding author's E-mail: Idhlester@gmail.com
}

Received: 11-09-2020; Revised: 24-11-2020; Accepted: 02-12-2020; Published on: 15-12-2020.

\section{ABSTRACT}

The association of the six plants in the form of hydroalcoholic extract, which has been shown to have therapeutic effects on people's health. To determine the safety of the association of the hydroalcoholic extract of the Curcuma longa rhizome; Cordia lutea flowers, Annona muricata leaves, Citrus aurantifolia fruit, Myrciaria floribunda fruit and Aspidosperma spruveanum leaves. The experimental design, 40 Holtzman rats ( 20 males - 20 females) were used; the guidelines or standards of the Organization for Economic Cooperation and Development were followed. The study was performed in the Pharmacology department of Universidad Nacional Mayor de san Marcos for 28 days. The hydroalcoholic extract was administered orally for 28 days, observations, signs and weekly evolution of the body weight of the animals were made; at the end, a blood sample was taken for hematological and biochemical study; then they were sacrificed for anatomopathological study of liver, kidney; ANOVA was applied, considering $p$ value $<0.05$ for significance. When the association was administered in the form of a hydroalcoholic extract, a homogeneous temporal evolution of body weight was observed. There was no significant variation in the levels of glycemia, urea, cholesterol, triglycerides, indirect bilirubin, transaminases, alkaline phosphatase and hemoglobin ( $p>0.05$ ); The findings show that the hydroalcoholic extract of this association of plants is not toxic in rats, when administered for a period of 28 days.

Keywords: Acute toxicity; Curcuma longa; Cordia, Annona, Soursop.

QUICK RESPONSE CODE $\rightarrow$

DOI:

10.47583/ijpsrr.2020.v65i02.008

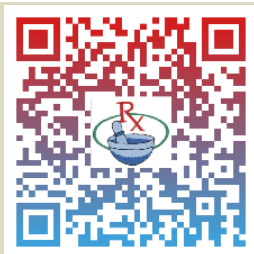

DOI link: http://dx.doi.org/10.47583/ijpsrr.2020.v65i02.008

\section{INTRODUCTION}

P lants are a rich source of metabolites useful for the preservation and health care ${ }^{1}$, the extracts obtained from their various parts have medicinal properties available in various pharmaceutical formulations ${ }^{2}$.

Traditional oriental medicine frequently uses the association of plants to treat chronic diseases, such as hyperlipidemia and obesity ${ }^{3}$. Ideally, the association of various active principles aims to generate synergism to increase the therapeutic effect and reduce adverse effects 4; however, if the association has similar pharmacokinetic characteristics, it could generate toxicity during metabolism and elimination; The degree of toxicity produced depends on the plasma concentrations, the dose and the duration of therapy ${ }^{5}$; chronic diseases such as diabetes mellitus, cardiovascular disease, and cancer represent a serious health problem ${ }^{1}$ that requires prolonged therapy, thereby increasing the risk of producing toxicity ${ }^{6}$.
Curcuma longa, known as stick, goes to the Zingiberaceae family, is widely cultivated in Asia and Africa ${ }^{7}$; Curcumin is the main metabolite, it has anti-inflammatory and antioxidant properties, demonstrating efficacy in the prevention of cancer and in the suppression of tumor growth 8; likewise, it contains essential oils, phenols, tannins, flavonoids, terpenes and alkaloids ${ }^{9}$; effective in treating infections ${ }^{10}$; Furthermore, it has been shown that Curcuma longa has been useful in the treatment of hyperlipidemias, increasing HDL, and reducing LDL and triglycerides ${ }^{11}$; Likewise, it is attributed a hepatic and renal protective effect on metal toxicity ${ }^{7}$, and anticonvulsant effects attributed to the sesquiterpenes present ${ }^{12}$.

Cordia lutea, known as flower of overo, is used to treat gastrointestinal, respiratory and dermatological disorders ${ }^{13}$; Like Cordia Verbenaceae, it has antitumor activity in vitro, as it reduces proliferation and viability, inducing apoptosis, and increasing the cytotoxic and antitumor effect 14; its essential oils have antiinflammatory effects, which is why it is recommended in acute inflammation ${ }^{15}$.

Annona muricata, known as soursop, goes to the Annonaceae family, it is distributed in South America, Central America, West Africa and southeast Asia ${ }^{1} ; 220$ components have been identified in the plant, mainly flavonoids, tannins and glycosides ${ }^{16}$, acetogenins and alkaloids ${ }^{1}$; Some studies indicate antipyretic and sedative effects, useful in the treatment of respiratory diseases, 
malaria, gastrointestinal disorders, alterations to the liver, heart and kidneys 1, 2,16, 19; Likewise, it has antiproliferative activity in human prostate cancer tumor cells (PC-3 cell) in in vitro studies ${ }^{17}$; and induce $\mathrm{G} 1$ cycle arrest and apoptosis in colon cancer cells ${ }^{18}$; they retain a chemoprotective effect in breast cancer induced by DMBA ${ }^{19}$, a hypoglycemic effect for the treatment of diabetes mellitus, antioxidant activity in vivo and a protector of beta cells of the pancreas ${ }^{20}$.

The genus Citrus (aurantifolia) is one of the greatest consumed and distributed fruits in the world. Several examples of the use of citrus fruits as therapeutic remedies including the use of orange, lime and lemon juices like remedies for the prevention of kidney stone; the use of citrus flavonoids as effective in vivo agents can modulate the metabolism of liver lipids; using orange juice to prevent inflammatory processes; the use of polyphenolics from calamondin and kumquat peel as effective antioxidant agents; the use of grapefruits as agents that can low the blood pressure and interfering with calcium channel blockers; the use of grapefruit as a snack and stomach tonic; the use of lemon juice with honey to relieve cough. There are some health benefits, like anti-cancer, antimutagenic, anti-allergic, and anti-aging activities of polyphenols ${ }^{21}$.

Myrciaria floribunda, known like "camboim", "jabuticabinha", "murta", "duque", "goiabarana" and "araçazeiro" is native from Brazil" ${ }^{23}$. The essential oil of M. floribunda has been reported rich in terpenoid compounds and biological activities like antimicrobial, anticholinesterase, antitumor and insecticidal. Just, a previous study with $M$. floribunda leaves reported that its ethyl acetate extract has phenolic compounds and flavonoid myricetin-3-galoctoside was identified. As flavonoids are known like anticancer and antioxidant agents, this drives us to assess the antiproliferative activity in tumor cell lines and determine the antioxidant capacity in the content of total phenolics, flavonoids and tannins of the extract of the leaves of M. floribunda, ${ }^{22}$.

Representatives of the genus Aspidosperma are since Mexico to Argentina ${ }^{24}$, and several species have traditionally used for malaria ${ }^{25-28}$. A recent review of the traditional use and antimalarial activity of Aspidosperma species revealed several scientific literature references on the use of 24 species to treat malaria / fevers, including Aspidosperma parviflorum, and 19 Aspidosperma species that have had their extracts and / or alkaloids evaluated for antimalarial activity in vitro and / or in vivo showing positive results. The ethanol extract of the bark of the trunk of Aspidosperma parviflorum provided ulein which reveals a high antimalarial activity in vitro and selectivity. Furthermore, the alkaloid fraction showed antimalarial activity similar to ulein. The high chemical diversity of alkaloids of Aspidosperma species and the small number of these alkaloids that have been analyzed to determine antimalarial activity, together with the traditional use of several species of this taxon for the treatment of malaria, also in other Meso and South American countries, deepen the research of plants of this genus of great interest in the search for natural medicines against malaria, ${ }^{29}$.

\section{MATERIALS AND METHODS}

Preparation of aqueous ethanol extract of the association of the rhizome of Curcuma longa; Cordia lutea flowers, Annona muricata leaves, Citrus aurantifolia fruit, Myrciaria floribunda fruit and Aspidosperma spruveanum leaves

All plants were sun dried within the temperature range of $30-42^{\circ} \mathrm{c}$ for 5 days before being reduced in size to a coarse powder with an electric grinder. the coarse plant powder weighing $1000 \mathrm{~g}$ was extracted with $90 \%$ aqueous ethanol in three cycles using a Soxhlet extractor. the crude extract was filtered with Whatman no. 4 filter paper and the filtrate was concentrated in vacuo at $30^{\circ} \mathrm{c}$ to obtain $80 \mathrm{~g}$ of weight of the residue $(8.7 \% \mathrm{w} / \mathrm{w})$. the residue was stored in an airtight bottle, kept in a refrigerator at $4^{\circ} \mathrm{C}$ until use.

The toxicity evaluation at repetitive dose for 28 days by oral route was performed according to the standards of the organization for economic cooperation and development standard 407; 40 rats of the Holtzman line of 7 months, 20 males and 20 females, with an average weight of $350 \pm 20 \mathrm{~g}$ and $275 \pm 20 \mathrm{~g}$ respectively, were used, which were acquired at the national health institute (ins, lima-Peru) and installed, for air conditioning for 48 hours, in the Bioterium of the faculty of human medicine unmsm, at an ambient temperature $\left(22-26^{\circ} \mathrm{c}\right)$, humidity of $60-70 \%$ with 12 -hour light / dark cycles they were given water and food ad libitum. four groups of ten rats (five males and five females) were randomly formed: group i: ssf $2 \mathrm{ml} / \mathrm{kg}$; groups ii, iii, iv: hydroalcoholic extract of curcuma longa rhizome, cordia lutea flowers and Annona muricata leaves, citrus aurantifolia fruit, Myrciaria floribunda fruit and Aspidosperma Spruveanum leaves at a dose of $100 \mathrm{mg} / \mathrm{kg}, 200 \mathrm{mg} / \mathrm{kg}$ and $400 \mathrm{mg} / \mathrm{kg}$ respectively, which were administered orally once a day for 28 days, the evaluation method was double blind.

The evolution of body weight was evaluated at $0,7,14,21$ and 28 days; on day 28 , the animals were subjected to general anesthesia (Halatal ${ }^{\circledR} 10 \mathrm{mg} / \mathrm{kg}$ ) for the extraction of blood by intracardiac puncture and to carry out hematological and biochemical studies, as indicated in table 1; then, the animals were sacrificed with an overdose of pentobarbital (Halatal ${ }^{\circledR} 100 \mathrm{mg} / \mathrm{kg}$ ) for the anatomopathological study.

The description of variables is expressed in means and standard deviation; the statistical comparison of groups, by means of one-way anova followed by a post-hoc turkey test, was considered significant with a $p<0.05$ at the $95 \%$ confidence interval. the statistical program Spss version 17 was used.

During the study, the specifications proposed by the institutional committee for the care and use of animals 
were followed, and the current regulations of the animal protection law (law 27265) were respected.

\section{RESULTS AND DISCUSSION}

The results show a tendency to increase the body weight of the rats that received the administration of the hydroalcoholic extract for 28 days, observing a homogeneous increase in both genders (figure 1) with the exception of the female rats of group ii (100 mg / kg) which reduced body weight during the last week.

The biochemical and hematological analysis at 28 days determined that there was no significant variation in the levels of glycemia, urea, cholesterol, triglycerides, indirect bilirubin, alanine aminotransferase (TGP), aspartate aminotransferase (TGO), alkaline phosphatase, hemoglobin, hematocrit, monocyte and lymphocyte count ( $p>0.05)$; however, significant changes $(p<0.05)$ were observed in group ii of female rats $(100 \mathrm{mg} / \mathrm{kg})$ as they presented decreased creatinine levels and male rats (200 $\mathrm{mg} / \mathrm{kg}$ ) presented reduction high-density lipoproteins (HDL); likewise, in group ii of male rats $(100 \mathrm{mg} / \mathrm{kg})$ there is evidence of an increase in total and direct bilirubin; likewise, leukocytosis is evidenced for group iv of male rats (table 1).

Table 1: Biochemical and hematological parameters when evaluating the acute toxicity of the rhizome association of Curcuma longa; Cordia lutea flowers, Annona muricata leaves, Citrus aurantifolia fruit, Myrciaria floribunda fruit and Aspidosperma spruveanum leaves when administered orally for 28 days in Holtzman rats.

\begin{tabular}{|c|c|c|c|c|c|c|c|c|}
\hline \multirow[t]{3}{*}{ Parameters } & \multicolumn{4}{|c|}{ Males } & \multicolumn{4}{|c|}{ Fémales } \\
\hline & SSF 2ML/ & 100 & 200 & 400 & SSF 2ML/ & 100 & 200 & 400 \\
\hline & KG & MG/KG & MG/KG & MG/KG & KG & MG/KG & MG/KG & MG/KG \\
\hline Glucose (MG/DL) & $85,2 \pm 12,2$ & $87,8 \pm 16,2$ & $90,4 \pm 9,8$ & $94,4 \pm 7,7$ & $87,6 \pm 7,7$ & $92,6 \pm 11,7$ & $85,2 \pm 12,2$ & $95,8 \pm 9,5$ \\
\hline Urea (MG/DL) & $21,2 \pm 6,3$ & $20,2 \pm 4,9$ & $18,6 \pm 5,5$ & $20,2 \pm 8,2$ & $19,0 \pm 6,4$ & $16,0 \pm 4,5$ & $20,0 \pm 5,9$ & $21,2 \pm 6,3$ \\
\hline Creatinin (MG/DL) & $0,8 \pm 0,1$ & $0,6 \pm 0,1$ & $0,7 \pm 0,2$ & $0,6 \pm 0,2$ & $0,7 \pm 0,1$ & $0,5 \pm 0,1^{B}$ & $0,7 \pm 0,1$ & $0,7 \pm 0,1$ \\
\hline Colesterol (MG/DL) & $145,8 \pm 37,1$ & $193,4 \pm 60,5$ & $155,8 \pm 32,4$ & $172,2 \pm 28,7$ & $156,6 \pm 21,9$ & $168,8 \pm 31,5$ & $165,4 \pm 20,1$ & $174,6 \pm 19,2$ \\
\hline HDL (MG/DL) & $58,6 \pm 10,9$ & $45,8 \pm 12,1$ & $43,4 \pm 5,1^{B}$ & $51,2 \pm 10,5$ & $47,2 \pm 6,9$ & $43,8 \pm 4,3$ & $43,8 \pm 4,3$ & $49,4 \pm 11,7$ \\
\hline Triglycerides (MG/DL) & $108,8 \pm 20,2$ & $136,0 \pm 33,1$ & $141,4 \pm 44,3$ & $152,6 \pm 38,3$ & $138,6 \pm 23,1$ & $166,6 \pm 31,6$ & $172,8 \pm 44,4$ & $133,0 \pm 6,2$ \\
\hline $\begin{array}{l}\text { Bilirrubin } \\
\text { (MG/DL) }\end{array}$ & $1,01 \pm 0,3$ & $2,19 \pm 0,5^{A}$ & $1,14 \pm 0,7$ & $1,39 \pm 0,5$ & $1,84 \pm 0,8$ & $1,21 \pm 0,4$ & $1,63 \pm 0,3$ & $1,06 \pm 0,1$ \\
\hline $\begin{array}{l}\text { Bilirrubin } \\
\text { (MG/DL) }\end{array}$ & $0,77 \pm 0,2$ & $1,63 \pm 0,2^{A}$ & $0,79 \pm 0,4$ & $0,98 \pm 0,3$ & $1,30 \pm 0,5$ & $0,89 \pm 0,2$ & $1,09 \pm 0,2$ & $0,75 \pm 0,1^{B}$ \\
\hline $\begin{array}{l}\text { Bilirrubina Indirecta } \\
\text { (MG/DL) }\end{array}$ & $0,23 \pm 0,1$ & $0,56 \pm 0,2$ & $0,35 \pm 0,3$ & $0,42 \pm 0,2$ & $0,54 \pm 0,3$ & $0,32 \pm 0,2$ & $0,54 \pm 0,1$ & $0,31 \pm 0,1$ \\
\hline TGP (UI/L) & $29,8 \pm 9,7$ & $33,6 \pm 7,4$ & $48,0 \pm 21,6$ & $27,8 \pm 10,2$ & $30,8 \pm 12,5$ & $31,2 \pm 20,0$ & $30,0 \pm 10,2$ & $28,8 \pm 6,4$ \\
\hline TGO (UI/L) & $42,6 \pm 11,6$ & $47,6 \pm 14,2$ & $61,8 \pm 37,3$ & $42,4 \pm 16,0$ & $43,2 \pm 16,4$ & $34,6 \pm 8,9$ & $38,4 \pm 12,5$ & $40,2 \pm 3,5$ \\
\hline $\begin{array}{l}\text { Alkaline Phosphatase } \\
\text { (UI/L) }\end{array}$ & $89,6 \pm 16,7$ & $85,2 \pm 14,3$ & $113,0 \pm 42,2$ & $101,4 \pm 13,1$ & $109,8 \pm 18,7$ & $117,0 \pm 19,2$ & $110,0 \pm 44,0$ & $92,0 \pm 22,1$ \\
\hline Hemoglobyn (G/DL) & $11,9 \pm 0,8$ & $12,5 \pm 0,8$ & $11,7 \pm 0,7$ & $12,7 \pm 0,8$ & $11,7 \pm 0,9$ & $12,7 \pm 1,1$ & $12,1 \pm 0,7$ & $12,2 \pm 1,8$ \\
\hline Hematocrit (\%) & $35,0 \pm 2,9$ & $36,4 \pm 4,6$ & $37,4 \pm 1,5$ & $38,0 \pm 3,1$ & $34,2 \pm 1,9$ & $39,2 \pm 4,3^{B}$ & $32,8 \pm 4,8$ & $35,6 \pm 5,5$ \\
\hline Leucocites (X 103/ $\mu \mathrm{L})$ & $6,8 \pm 1,7$ & $7,5 \pm 2,0$ & $8,1 \pm 1,3$ & $9,0 \pm 0,4^{B}$ & $6,7 \pm 2,0$ & $5,7 \pm 1,2$ & $6,0 \pm 1,3$ & $6,6 \pm 0,9$ \\
\hline Lymphocytes (\%) & $35,8 \pm 6,3$ & $35,8 \pm 8,9$ & $34,4 \pm 74,4$ & $39,4 \pm 11,1$ & $34,4 \pm 7,9$ & $32,2 \pm 11,7$ & $41,2 \pm 7,8$ & $37,2 \pm 7,4$ \\
\hline Monocites (\%) & $1,2 \pm 1,3$ & $1,2 \pm 1,7$ & $1,0 \pm 1,7$ & $0,2 \pm 0,4$ & $1,0 \pm 0,7$ & $1,8 \pm 1,3$ & $0,6 \pm 0,8$ & $1,4 \pm 1,6$ \\
\hline
\end{tabular}

SSF: serum fi; Mean \pm SD. ANOVA, Tukey test a Vs SSF Group $(p<0.01)$ b Vs SSF Group $(p<0.05)$
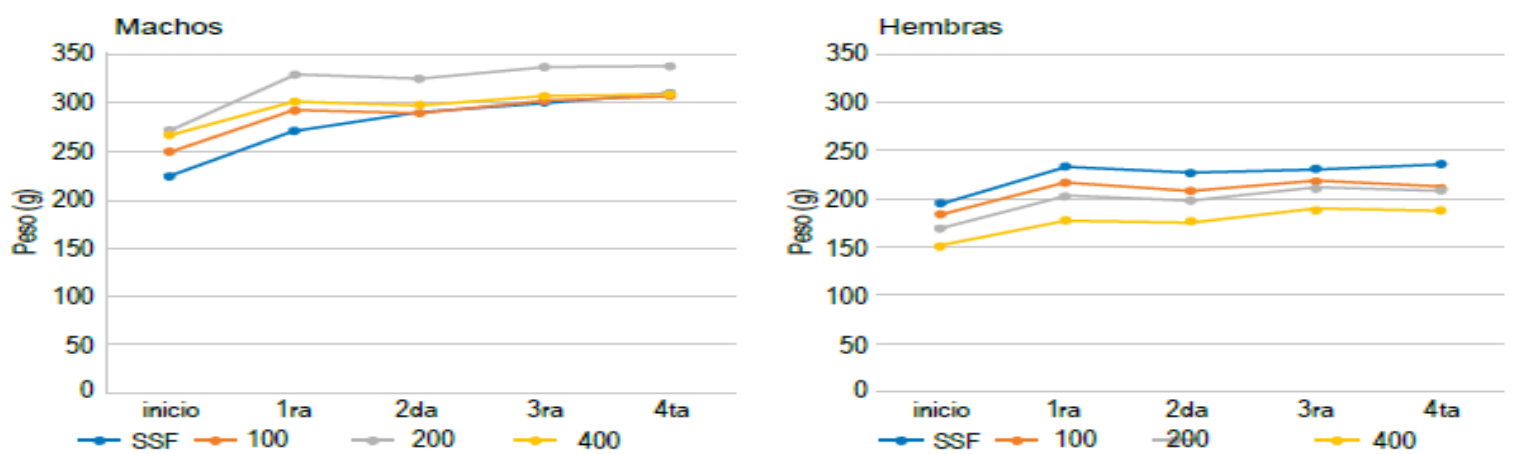

Figure 1: Variation of the body weight of the Holtzman rats that receive the oral administration of the hydroalcoholic association of the curcuma longa rhizome

Association; Cordia lutea flowers, Annona muricata leaves, Citrus aurantifolia fruit, Myrciaria floribunda fruit and Aspidosperma spruveanum leaves for 28 days. 


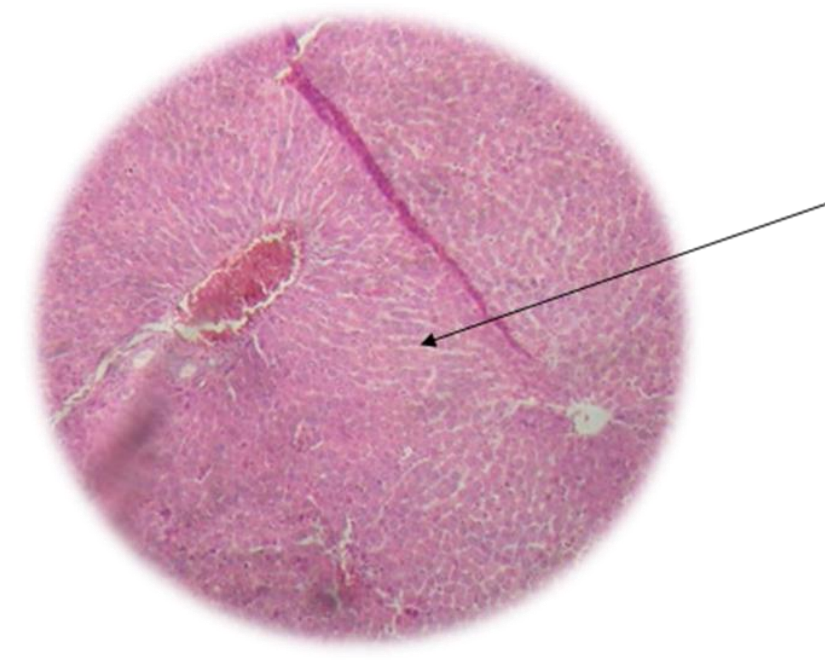

Liver without Histological Alterations (40X).

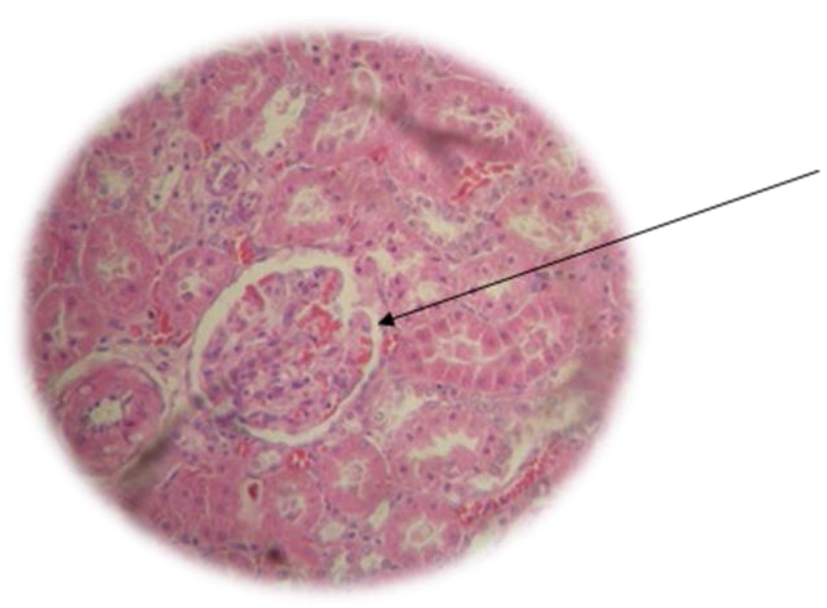

Kidney with Preserved Histological Structure (40X).

Figure 2: Histological manifestations in Holtzman rats that receive oral administration of the hydroalcoholic extract of the association of Cordia lutea, Annona muricata leaves, Citrus aurantifolia fruit, Myrciaria floribunda fruit and Aspidosperma Spruveanum leaves be administered orally for 28 days.

(The macroscopic and histopathological evaluations do not show signs of toxicity; liver and kidney assessment were performed (Figure 2), observing normal tissues)

\section{DISCUSSION}

Since ancient times, botanical medicine represents a therapeutic alternative, many agencies in the world have issued regulations related to the safety of herbal medicines, in order to protect and promote public health ${ }^{22}$; these drugs have shown various effects: anti-inflammatory, antineoplastic, hepatic protectors, in vitro and in vivo antioxidants, antimicrobial, sedative, hypnotic, among others ${ }^{4}$; prolonged therapies, necessary for the treatment of chronic diseases, increase the risk of nephrotoxicity and hepatoxicity ${ }^{23}$, in addition, in some chronic diseases, such as the treatment of neoplasms, the prolonged use of standard drugs leads to the appearance of adverse effects severe, such as hair loss, anemia, gastrointestinal disorders, leukemia, resistance to chemotherapeutics ${ }^{6}$; the demand for these products has led to the need to evaluate not only efficacy, but also safety concerns ${ }^{24}$.

The research has been carried out with the objective of determining the safety of the association of the hydroalcoholic extract of Curcuma longa rhizome; Cordia lutea flowers, Annona muricata leaves, Citrus aurantifolia fruit, Myrciaria floribunda fruit and Aspidosperma spruveanum leaves, administered orally to rats once a day for 28 days. observations indicate that there were no significant changes in body weight between the groups, nor were there any clinical changes (figure 1); modification of food intake is considered an indicator of toxicity ${ }^{22}$.

It is also observed that the levels of transaminases do not present significant differences; it should be mentioned that the liver is the organ most affected by the acute or chronic presence of foreign substances, which are exposed directly after oral absorption through the first-pass liver phenomenon or later by metabolism ${ }^{22}$; the plants under study contain various metabolites, useful for the treatment of pathological conditions 1, 7, 10, 11, 13-20, the flavonoids present in the aqueous extract $[9,16]$ are reported as hepatoprotector ${ }^{25}$. furthermore, possibly at the dose levels used, the chemical components contributed by the three medicinal plants would have maintained an important balance, in such a way that it did not induce liver damage (figure 2).

Creatinine levels are considered as markers of renal impairment, they depend directly on body mass ${ }^{22,25}$; it is evidenced that the female rats of group ii $(100 \mathrm{mg} / \mathrm{kg}$ ) reduced creatinine levels, and this coincides with the weight loss during the last week (table 1). the hematopoietic system is very sensitive to toxic substances 26; this indicates the safety of the Curcuma longa rhizome association; Cordia lutea flowers, Annona muricata leaves, Citrus aurantifolia fruit, Myrciaria floribunda fruit and Aspidosperma spruveanum leaves as there were no hematological changes. the evaluation of pathological changes, by macroscopy and microscopy, are indicators of toxicity ${ }^{27}$, in the macroscopic analysis of the tissues at all the doses tested, it did not produce changes in the vital organs of the treated animals; likewise, in the histopathological, there were no suggestive signs of toxicity; these results coincide with what was found in the hematological and biochemical parameters (table 1, figure 2).

\section{CONCLUSION}

It is concluded that the administration of the hydroalcoholic extract of the rhizome association of curcuma longa; cordia lutea flowers, Annona muricata leaves, citrus aurantifolia fruit, Myrciaria floribunda fruit and Aspidosperma Spruveanum rats leaves for 28 days, does not present acute and subacute toxicity, as evidenced by clinical, hematological, biochemical and histopathological 
parameters; thus, demonstrating the safety of the atomized extract at the tested doses.

It is recommended to continue studies according to the standards of regulatory bodies, such as studies of chronic toxicity, reproductive toxicity, genotoxicity, endocrine changes, among others, in order to evaluate the total safety for use in humans.

Acknowledgements: To Sabell Perú S.A.C., for providing the goods and others, necessary to carry out the investigation. To the technician Mr. Madrid for the constant help in our projects for the care of the test animals.

\section{Competing Interests}

Authors have declared that no competing interests exist.

\section{Authors' Contributions}

Both Authors contribute with the totally like: designed the study, performed the statistical analysis, wrote the protocol, and wrote the first draft of the manuscript. managed the analyses of the study. managed the literature searches and read and approved the final manuscript.

\section{REFERENCES}

1. Coria - Telles AV, Montalvo - González E, Yahia E-M, Obledo - Vásquez EN. Annona muricata: A comprehensive review on its traditional medicinal uses, phytochemicals, pharmacological activities, mechanisms of action and toxicity. Arabian Journal of Chemistry, Volume 11, Issue 5, 2018, Pages 662-691. doi: http://dx.doi.org/10.1016/j.arabjc.2016.01.004

2. Prasad GJ, Wattamwar AS. Annona reticulata Linn. (Bullock's heart): Plant profile, phytochemistry and pharmacological properties. Journal of Traditional and Complementary Medicine, Volume 5, Issue 3, July 2015, Pages 144-152. doi: http://dx.doi.org/10.1016/j.jtcme.2015.04.001

3. Jong-Min H, Jin-Seok L, Hyeong-Geug K, In-Chan S, HwiJin I, Jung-Hyo $C$. et al. Synergistic effects of Artemisia iwayomogi and Curcuma longa radix on high-fat diet-induced hyperlipidemia in a mouse model. Journal of Ethnopharmacology, Volume 15, 2015, pages:173:217-24. http://dx.doiorg/10.1016/i.jep.2015.07.021

4. Efferth T. Perspectives for Globalized Natural Medicines. Chinese Journal of Natural Medicines, Volume 9, Issue 1, January 2011, Pages 1-6 2011. doi: http://dx.doi.org/10.1016/S1875-5364(11)60010-1

5. Ernst E. Pharmaceutical Toxicology. Principles of Translational Science in Medicine (Second Edition). 2015. doi:10.1016/B978-0-12-800687-0.00028-1

6. Barroso - Sousa R, Santana LA, Testa L, Gagliato D, Mano MS. Biological therapies in breast cancer: Common toxicities and management strategies. The breast, Volume 22, Issue 6, 2013, pages: 1009-1018. doi: http://dx.doi.org/10.1016/i.breast.2013.09.009

7. Wang, H, Su G, Chen G, Bai J, Pei Y. 1 H NMR-based metabonomics of the protective effect of Curcuma longa and curcumin on cinnabar-induced hepatotoxicity and nephrotoxicity in rats. Journal of Functional Foods, Volume
17, August 2015, Pages 459-467. doi: http://dx.doi.org/10.1016/j.jff.2015.04.014

8. Cunha CC, Marcelino PH, Dos Santos Filho EX, De Ávila RI, Carvalho A, Goncalves S, et al. Use of Bidens pilosa L. (Asteraceae) and Curcuma longa L. (Zingiberaceae) to treat intestinal mucositis in mice: toxico-pharmacological evaluations. Toxicology Reports, Volume 3, 2016, Pages 279-287.

doi:

http://dx.doi.org/10.1016/j.toxrep.2015.10.013

9. Freire RA, Vistel M. Phytochemicals characterization of Curcuma longa L. Revista Cubana Química, Volume 27,2015, Issue 1 1, pages:9-18. http://scielo.sld.cu/pdf/ind/v27n1/ind01115.pdf

10. Gupta A, Mahajan S, Sharma R. Evaluation of antimicrobial activity of Curcuma longa rhizome extract against Staphylococcus aureus. Biotechnology reports, Volume 6, 2015, pages: 51-55. doi: http://dx.doi.org/10.1016/i.btre.2015.02.001

11. Han JM, Lee JS, Kin HG, Seol I, Im HJ, Cho JH, et al. Synergistic Effects of Artemisia iwayomogi and Curcuma longa radix on high fat diet-induced hyperlipidemia in a mouse model. Journal of Ethnopharmacology, Volume 15, Issue 173, 2015, pages: 217-24. doi: http://dx.doi.org/10.1016/i.jep.2015.07.021

12. Orellana - Paucar AM, Serruys AS, Afrikanova T, Maes J, Borggraeve W, Alen J, et al. Anticonvulsant activity of bisabolene sesquiterpenoids of Curcuma longa in zebrafish and mouse seizure models. Epilepsy \& Behavior, Volume 24, Issue 1, 2012, pages :14-22. doi: http://dx.doi.org/10.1016/j.yebeh.2012.02.020

13. Hernández T, Canales M, Terán B, Ávila O, Duran A, García $A M$, et al. Antimicrobial activity of the essential oil and extracts of Cordia curassavica (Boraginaceae). Journal of Ethnopharmacology, Volume 111, Issue 1, 2007, pages:137141. http://dx.doiorg/10.1016/j.jep.2006.11.002

14. Parisotto EB, Michielin EM, Biscaro F, Ferreira SR, Wilhelm $D$, Pedrosa RC. The antitumor activity of extracts from Cordia verbenácea D.C. obtained by supercritical fluid extraction. The Journal of Supercritical Fluids, Volume 61, 2012, pages :101-107. doi: http://dx.doi.org/10.1016/j.supflu.2011.08.016

15. Passos GF, Fernandes ES, Da Cunha FM, Ferreira J, Pianowsky LF, Campos MM, et al. Anti-inflammatory and anti-allergic properties of the essential oil and active compounds from Cordia verbenácea. Journal of Ethnopharmacology, Volume 21, Issue 110(2), 2007, pages :323-33. doi: http://dx.doi.org/10.1016/j.jep.2006.09.032

16. Arroyo J, Martines J, Ronceros $G$, Palomino R, Villareal A, Bonilla $\mathrm{P}$, et al. Efecto hipoglicemiante coadyuvante del extracto etanólico de hojas de Annona muricata $L$ (guanábana), en pacientes con diabetes tipo 2 bajo tratamiento de glibenclamida. Anales de la Facultad Medicina, Volume 70, Issue 3, 2009, pages :163-7. doi: http://dx.doi.org/10.15381/anales.v70i3.934

17. Sun S, Liu J, Zhou N, Zhu W, Dou QP, Zhou K. Isolation of Three New Annonacous Acetogenins from Graviola Fruit (Annona muricata) and their Anti-Proliferation on Human Prostate Cancer Cell PC-3. Bioorganic \& Medicinal Chemistry Letters, Volume 1, Issue 26(17), 2016, pages :4382-5. doi: http://dx.doi.org/10.1016/j.colsurfb.2013.08.032 
18. Zorofchian S, Karimian H, Rouhollani E, Paydar $M$, Fadaeinsab M, Kadir $\mathrm{H}$, et al. Annona muricata leaves induce G1 cell cycle arrest and apoptosis through mitochondria mediated pathway in human HCT-116 and HT-29 colon cancer cells. Journal of Ethnopharmacology, Volume 28, Issue 156, 2014, pages :277-89. doi: http://dx.doi.org/10.1016/j.jep.2014.08.011

19. Minari J, Okeke U. Chemopreventive effect of Annona muricata on DMBA-induced cell Proliferation in the breast tissues of female albino mice. Egyptian Journal of Medical Human Genetics, Volume 15, Issue 4, 2014, pages :327-334. doi: http://dx.doi.org/10.1016/j.ejmhg.2014.05.001

20. Ngueguim F, Massa ZB, Kouamouo J, Tchuidjang A, Dzeufiet DP, Kamtchouing P. Antidiabetic and antioxidant Effects of Annona muricata (Annonaceae), aqueous extract on streptozotocin-induced diabetic rats. Journal of Ethnopharmacology, Volume 151, Issue 2, 2014, pages :784790. doi: http://dx.doi.org/10.1016/j.jep.2013.09.021

21. Lin LY, Chuang $\mathrm{CH}$, Chen HC, Yang KM. Lime (Citrus aurantifolia (Christm.) Swingle) Essential Oils: Volatile Compounds, Antioxidant Capacity, and Hypolipidemic. The Effect Journal, Volume 8, Issue 9, 2019, pages :398. https://doi:10.3390/foods 8090398

22. Tietbohl LAC, Oliveira AP, Esteves RS, Albuquerque RD, Folly $D$, Machado FP et al. Antiproliferative activity in tumor cell lines, antioxidant capacity and total phenolic, flavonoid and tannin contents of Myrciaria floribunda. Anais da Academia Brasileira de Ciencias, Volume 89, Issue 2, 2017, pages :1111-1120. https://doi:10.1590/0001-3765201720160461

23. SOBRAL M, PROENÇA C, SOUZA M, MAZINE F AND LUCAS E. Myrtaceae in Lista de Espécies da Flora do Brasil. Jardim Botânico do Rio de Janeiro, 2015. Disponible en: http://floradobrasil.jbri.gov.br/jabot/floradobrasil/FB171
24. Milliken W, Albert B. The use of medicinal plants by the Yanomami Indians of Brazil. Economic Botany Journal, Volume 50, 1996, pages :10-25.

\section{https://doi.org/10.1007/BF02862108}

25. Dolabela MF, Oliveira SG, Pérez JM, Nascimento JM, Povoa $M M$, Oliveira $A B$. In vitro antimalarial activity of six Aspidosperma species from the state of Minas Gerais (Brazil). Anais da Academia Brasileira de Ciencias, Volume 84, Issue 4, 2012, pages :899-910. https://doi.org/10.1590/\$0001-37652012000400005

26. Mariath IR, Falcão HS, Barbosa-Filho JM, Sousa LCF, Tomaz ACA, Batista LM, et al. Plants of the American continent with antimalarial activity. Revista Brasileira de Pharmacognosia, Volume 19, Issue 1a,2009, pages: 158-191. https://doi.org/10.1590/S0102-695X2009000100026

27. Milliken W, Albert B. The use of medicinal plants by the Yanomami Indians of Brazil. Part II. Economic Botany, Volume 51, 1997, pages :264-78. https://doi.org/10.1007/BF02862096

28. Oliveira $A B$, Dolabela MF, Braga FC, Jacome RL, Varotti FP, Povoa MM. Plant-derived antimalarial agents: new leads and efficient phythomedicines. Part I. Alkaloids. Anais da Academia Brasileira de Ciencias, Volume 81, Issue n4, 2009, pages :715-40. https://doi.org/10.1590/S0001$\underline{37652009000400011}$

29. Dolabela MF, Póvoa MM, Celio G, Dutra F, Ferreira L, De Paula RC, et al. "Aspidosperma species as sources of antimalarials: uleine is the major anti-malarial indole alkaloid from Aspidosperma parvifolium (Apocynaceae)." Malaria journal, Volume 13, Issue 1, 2015, pages: 1-12. https://doi: 10.1186/s12936-015-0997-4.

Source of Support: None declared.

Conflict of Interest: None declared.

For any question relates to this article, please reach us at: editor@globalresearchonline.net New manuscripts for publication can be submitted at: submit@globalresearchonline.net and submit_ijpsrr@rediffmail.com 